\title{
Influences of Wind and Snow on Northern Tree-Line Environments at Churchill, Manitoba, Canada
}

\author{
PETER A. SCOTT, ${ }^{1}$ ROGER I.C. HANSELL ${ }^{1}$ and WILLIAM R. ERICKSON ${ }^{2}$
}

(Received 26 August 1992; accepted in revised form 19 January 1993)

\begin{abstract}
The influences of wind and snow distribution at the tree line near Churchill, Manitoba, were studied. Wind profiles above the snow surface, snow crystal size and quantity were examined during abrasion experiments with white spruce branchlets. For white spruce, the abrasion zone was evidently within $80 \mathrm{~cm}$ above the snow surface, and needle removal by abrasion was strongly influenced by branch age. Removal by abrasion of similar-aged needles was highest in new branches and declined with branch age up to 7 or 8 years, and then increased again with older branches. Trees that grew $80 \mathrm{~cm}$ in height in 7 or 8 years were successful in passing through the abrasion zone.

In forest-tundra environments the matted forms of trees were snow covered early in winter and received little abrasion. Sparsely needled islands of trees were largely covered with snow at the base. More densely needled trees and some trees within woodlands were less exposed to abrasion. The blockage of air flow resulted in high-speed jets, which cleared out snow within a "horseshoe-shaped vortex" around the base of the tree. Both in much of the woodlands and in the open forest, snow abrasion was minimal or non-existent and snow load on the branches (qali) becomes the prevalent stress.

During winter, a large proportion of the snowfall was initially blown off the exposed surfaces of Hudson Bay and the coastal tundra regions, into the woodlands, and eventually across the tree line and into the open forest. As the woodlands filled up with snow in mid-winter, the rate of snow accumulation in the forest increased from double to triple the snowfall. Variations in the rate of accumulation occurred with wind speed and direction.

During May, snowmelt began on exposed tundra first and usually ran off the frozen surface. Snowmelt occurred about three weeks later in the open forest and was characterized there by less runoff, as the water more readily permeated the thawing peat. The late snow beds are characteristic of the forest-tundra woodlands and were usually gone by mid-July. The woodlands were snow free for 1.5-2 months during the year, while the open forest was snow free for about 3 months and the tundra was largely snow free for 6 months or more.

Key words: tree line, wind, snow, white spruce, abrasion
\end{abstract}

RÉSUMÉ. L'influence de la distribution du vent et de la neige à la limite forestière, près de Churchill, au Manitoba, constitue le thème de cette recherche. On a étudié le profil éolien au-dessus de la surface de la neige, ainsi que la taille et la quantité des cristaux de neige au cours d'expériences d'abrasion faites sur des petites branches d'épinette blanche. Pour cette dernière, la zone d'abrasion se situait de toute évidence dans les $80 \mathrm{~cm}$ au-dessus de la surface de la neige et la disparition des aiguilles par abrasion était fortement influencée par l'âge de la branche. La disparition par abrasion des aiguilles d'âge semblable était plus élevée pour les nouvelles branches et diminuait avec l'âge de la branche, jusqu'à 7 ou 8 ans, pour augmenter à nouveau avec les branches plus vieilles. Les arbres qui poussaient de $80 \mathrm{~cm}$ en 7 ou 8 ans réussissaient à traverser la zone d'abrasion.

Dans les environnements de toundra boisée, les arbres aux formes tassées et enchevêtrées étaient couverts de neige tôt en hiver et étaient peu sujets à l'abrasion. Les îlots d'arbres aux aiguilles clairsemées étaient largement couverts de neige à la base. Les arbres aux aiguilles plus fournies et quelques arbres de la forêt-parc étaient moins exposés à l'abrasion. Le blocage de la circulation d'air créait des courants très rapides qui soufflaient la neige en créant un tourbillon en fer à cheval au pied de l'arbre. Dans la plupart de la forêt-parc comme dans la forêt claire, l'abrasion par la neige était minime ou non existante et la charge nivale sur les branches (qali) était le principal agent de stress.

$\mathrm{Au}$ cours de l'hiver, une grande quantité de la chute nivale était d'abord transportée par le vent, depuis la surface exposée des régions de la baie d'Hudson et de la toundra côtière, jusqu'à la forêt-parc, puis dépassait la limite forestière pour entrer dans la forêt claire. Comme la forêt-parc se remplissait de neige au milieu de l'hiver, le taux d'accumulation nivale dans la forêt passait du double au triple de la chute de neige. La vitesse et la direction du vent faisaient varier le taux d'accumulation.

Durant le mois de mai, la fonte nivale se produisait d'abord dans la toundra et ruisselait en général sur la surface gelée. La fonte nivale se produisait environ 3 semaines plus tard dans la forêt claire et s'y caractérisait par une réduction du ruissellement, du fait que l'eau s'infiltrait plus facilement dans la tourbe en dégel. Les combes de neige tardives étaient caractéristiques de la toundra boisée de la forêt-parc et avaient généralement disparu au milieu de juillet. La forêt-parc était libre de neige pendant 1 mois et demi à 2 mois au cours d'une année, alors que la forêt claire était libre de neige durant environ 3 mois et la toundra pratiquement libre de neige durant au moins 6 mois.

Mots clés : limite forestière, vent, neige, épinette blanche, abrasion

Traduit pour le journal par Nésida Loyer.

\section{INTRODUCTION}

In tree-line ecosystems, the importance of wind in winter is demonstrated by its effects: desiccation by wind (Wardle, 1981; Frey, 1983), abrasion by wind-driven snow particles (Hadley and Smith, 1987, 1989), and friction from strong winds (Grier, 1988), which can severely damage overwintering trees. The redistribution of snow by wind may result in the protection of trees from negative wind effects during winter (Marr, 1977; Hadley and Smith, 1983, 1987) but also can cause severe damage during snowmelt (Payette and Filion, 1985; Lavoie and Payette, 1992). Within the tree line, trees have reached sufficient density to buffer the direct wind effects and subsequently modify their environment. Beyond the tree line, trees are more scattered and different stresses are prevalent. One distinction is the recognition of different (apparently wind-generated) crown forms (Yoshino, 1973; Payette, 1974; Scott et al., 1987; Stevens and Fox, 1991). Unique tree responses to wind stress indicate variations in physical environments in the area of the tree line and that a classical ecotone or gradient approach to snow-loaded forests and wind-abraded islands of tree shrubs may be an oversimplication of separate and discrete systems. Identifying

\footnotetext{
'Department of Zoology, University of Toronto, Toronto, Ontario, Canada M5S 1A1

${ }^{2}$ Boreal Projects, Box 550, Churchill, Manitoba, Canada R0B OE0

(C)The Arctic Institute of North America
} 
the processes that lead to different crown forms is fundamental to understanding the development and subsequent stability of the open forest and forest-tundra systems around the tree line.

This study reports a series of experiments that complement descriptions of wind-generated processes occurring during winter in a tree-line region. First, the relevance of wind to the development of the zone of abrasion and the impact of that abrasion on needle and branch survival in white spruce (Picea glauca [Moench] Voss) are examined. Then the wind-speed and snow-depth profiles around different crown forms of spruce in their natural environment are evaluated. Finally, snow redistribution relative to the presence or absence of spruce individually, in islands and woodlands and within the open forest is compared and discussed relative to the snow-free period.

\section{METHODS}

\section{Regional Description}

The tree-line region around Churchill, Manitoba $\left(58^{\circ} 45^{\prime} \mathrm{N}\right.$, $94^{\circ} 04^{\prime} \mathrm{W}$ ) has been delineated using white spruce crown forms (Scott et al., 1987). An area close to Hudson Bay where trees are absent or stemless mats exist in low abundance is defined as tundra. The resultant boundary is similar to that from defining tundra by the extreme limit of trees in other studies (Tranquillini, 1979; Payette, 1983; Kullman, 1990). The forest-tundra is composed of wind-abraded islands of trees and occasional woodlands that have varying crown forms. The region where greater than $95 \%$ full-crowned trees are prevalent is defined as the open forest. The line between the open forest and the forest-tundra defines the tree line in this study.

\section{Tree Abrasion Zone}

The abrasion zone was defined by measuring two separate profiles of wind velocity above the snow surface. Two anemometers were wired to an encased CR21x (Campbell Scientific Instruments, Edmonton, Alberta) datalogger that was strapped to a komatik (sled) and heated with thermochemical Hot Shots (Johnson \& Johnson, Peterborough, Ontario). The reference anemometer measured wind speed at $1.6 \mathrm{~m}$ above the snow surface. The second anemometer measured wind speed at $25 \mathrm{~cm}$ intervals above the snow surface. The CR21x was programmed to integrate the wind speed over 20 second intervals and then average three such measurements. For each profile the procedure was repeated over a minimum of three minutes. The average wind speeds at each height interval were then converted to percentages of the reference wind speeds.

To examine the character of snow in the abrasion zone, ice crystals were captured and measured within the first metre above the snow surface. Glass vials were taped onto a grill at $1 \mathrm{~cm}$ intervals for the first $20 \mathrm{~cm}$, then $4 \mathrm{~cm}$ intervals up to $1 \mathrm{~m}$. The grill was placed in an exposed area and aligned so that the trapping vials were facing obliquely to the wind for a $12 \mathrm{~h}$ period with wind speeds averaging approximately $30 \mathrm{~km} \cdot \mathrm{h}^{-1}$ and exceeding $40 \mathrm{~km} \cdot \mathrm{h}^{-1}$. In a sheltered, unheated room, a minimum of 20 ice crystals were sampled from each vial, placed on a calibrated slide and examined under a microscope. The longest two axes were measured to the nearest $0.01 \mathrm{~mm}$ so that the cross-sectional area of the largest surface could be determined.

To relate the rate of vertical growth in white spruce at tree line to the effects of snow abrasion, four full-crowned and four abraded-crowned white spruce trees were initially chosen as a branch source. The eight trees were 40-60 years old, apparently healthy and appeared representative of local populations. For each tree the (undamaged) vertical growth over the last 12 years was measured and recorded.

The impact of wind and ice crystals on needle abrasion was examined during mid-February with 24 three-year-old tree-line white spruce branchlets. The branchlets were cut from the sample trees at random, weighed to the nearest $0.05 \mathrm{gm}$ with a triple beam balance (Ohaus, Florham Park, N.J. 07932, U.S.A.), and then stapled to wooden poles at $20 \mathrm{~cm}$ intervals (Scott and Hansell, 1992). In an exposed area each of the poles was pushed into the snow so that the branchlets ranged from 20 to $160 \mathrm{~cm}$ above the snow surface and was readjusted when necessary to maintain the branchlets at these levels. After 10 days each branchlet was removed from the posts and reweighed. The entire process was undertaken outside at ambient temperature.

To determine the susceptibility of the similar-aged needles from branches of variable age to abrasion, 96 two-year-old branchlets were cut from north-, south-, east- and west-facing branches of the third, seventh and eleventh whorls of the 8 white spruce sample trees. (Relative to needle viability, three-year-old branches would be young, seven-year-old mature and eleven-year-old senescent [Clark, 1961].) The branchlets were weighed in the field at ambient temperature with a sheltered triple beam balance. Random pairs were stapled horizontally to wooden stakes and maintained $10 \mathrm{~cm}$ above the snow surface for 7 days. The branchlets were examined and reweighed to determine change in weight. The change in water content during the experiment was corrected for by a negative exponential regression (see Scott and Hansell, 1992). The residual change in weight was attributed to needle loss.

\section{Wind Speed and Snow Distribution}

Patterns of wind stress around trees were examined by measuring wind speed at $1 \mathrm{~m}$ above the snow surface and snow depths on grids of $1 \mathrm{~m}$ intervals around a sparsely needled white spruce island, a densely needled spruce island and spruce trees within a woodland. Measurements began at the edge of the tree crowns on the four cardinal directions. Wind speeds were recorded using the dual anemometers described above and converted to percentages relative to an undisturbed reference value. Wind speed measurements were integrated over three 20-second intervals and replicated three times. Snow depths were also measured on the $1 \mathrm{~m}$ grid by pushing a calibrated metal rod through the snow layer.

The distribution of snow on typical exposed forest tundra was examined by measuring the snow depth on an 86-point grid at $10 \mathrm{~m}$ intervals. Snow depths were also measured at selected locations along a transect that passed through a 
forest-tundra woodland and in the open forest by taking a minimum of 30 random depth measurements at a location approximately $500 \mathrm{~m}$ inside the tree line. The snow depths were taken periodically over five winters (1987-88 to 1991-92) and repeated after selected snowfalls within a winter. In addition, other snow depth measurements were taken on lake ice and sea ice and around specific trees.

To determine snow density and water equivalents during mid-February, three $300 \mathrm{ml}$ samples were taken from the top, middle and bottom of five snow profiles from open forest and exposed forest tundra. Each sample was melted and the change in volume was recorded. Regional snowfall data and the respective snow-water equivalent were also provided by the Churchill Weather Office, Churchill, Manitoba. The staff at the Weather Office used an MSC Nypher Shielded Snow Gauge (Goodison et al., 1981) situated on a fully exposed level site $1.5 \mathrm{~m}$ above the ground. The periods of snow accumulation began after 1 November and were terminated before the first day of thaw in spring. This ensures that no melt had occurred.

\section{RESULTS}

The wind profiles (Fig. 1) were created during an ambient wind speed of around $20 \mathrm{~km} \cdot \mathrm{h}^{-1}$ and $30 \mathrm{~km} \cdot \mathrm{h}^{-1}$, typical of conditions during February. Wind speed increased exponentially above the snow surface, reaching $79 \%$ of the reference value by $25 \mathrm{~cm}$ and exceeding $90 \%$ by $75 \mathrm{~cm}$. Snow crystals were most numerous near the surface, where wind speed was least. There was a high frequency of hexagonal crystals (including sub-hedral, dihedral, II [c], 1, a; after Nakayana, 1954) near the snow surface, with increasing proportions of hollow tubes and horns (IV [CP] 3) above $10 \mathrm{~cm}$ and with winged crystals (III [C], $1, \mathrm{a}, \mathrm{c}$ ) dominating above $80 \mathrm{~cm}$. The cross-sectional area of the crystals within $1 \mathrm{~cm}$ of the snow surface was $0.230 \mathrm{~mm}^{2}$ ( $\mathrm{SD} \pm 0.190$ ). Crystal size declined rapidly with height, until at $10 \mathrm{~cm}$ the average crystal was $0.022 \mathrm{~mm}^{2}$ (SD \pm 0.017 ). The average cross-sectional area at $24 \mathrm{~cm}$ height was $0.009 \mathrm{~mm}^{2}(\mathrm{SD} \pm 0.009)$ and increased slightly above this, where a higher proportion of winged or kite-shaped crystals appeared.

The vertical growth of the abraded-crowned, forest-tundra trees averaged $11.8 \mathrm{~cm}$ (SD \pm 2.22 ), as compared to $13.2 \mathrm{~cm}$ (SD \pm 1.28 ) for the full-crowned, open forest trees over the past 12 years. In total, the average height growth of the eight sample trees was $12.5 \mathrm{~cm}$ (SD \pm 1.72 ), similar to other height increments measured in the area (Scott et al., 1987, 1988).

The three-year-old white spruce branchlets placed at $20 \mathrm{~cm}$ intervals above the snow surface for 10 days showed clear evidence of needle loss. Under average conditions the rate of needle loss approached $1 \%$ of the total branch weight per day in the first $40 \mathrm{~cm}$ above the snowpack (Fig. 1). The rate of weight loss declined to less than $10 \%$ of this value above $140 \mathrm{~cm}$. Significant and ongoing needle loss was restricted to the first $80 \mathrm{~cm}$ above the snowpack. Under severe blizzard conditions even for a few hours, complete loss of needles from branches near the snow surface was observed.
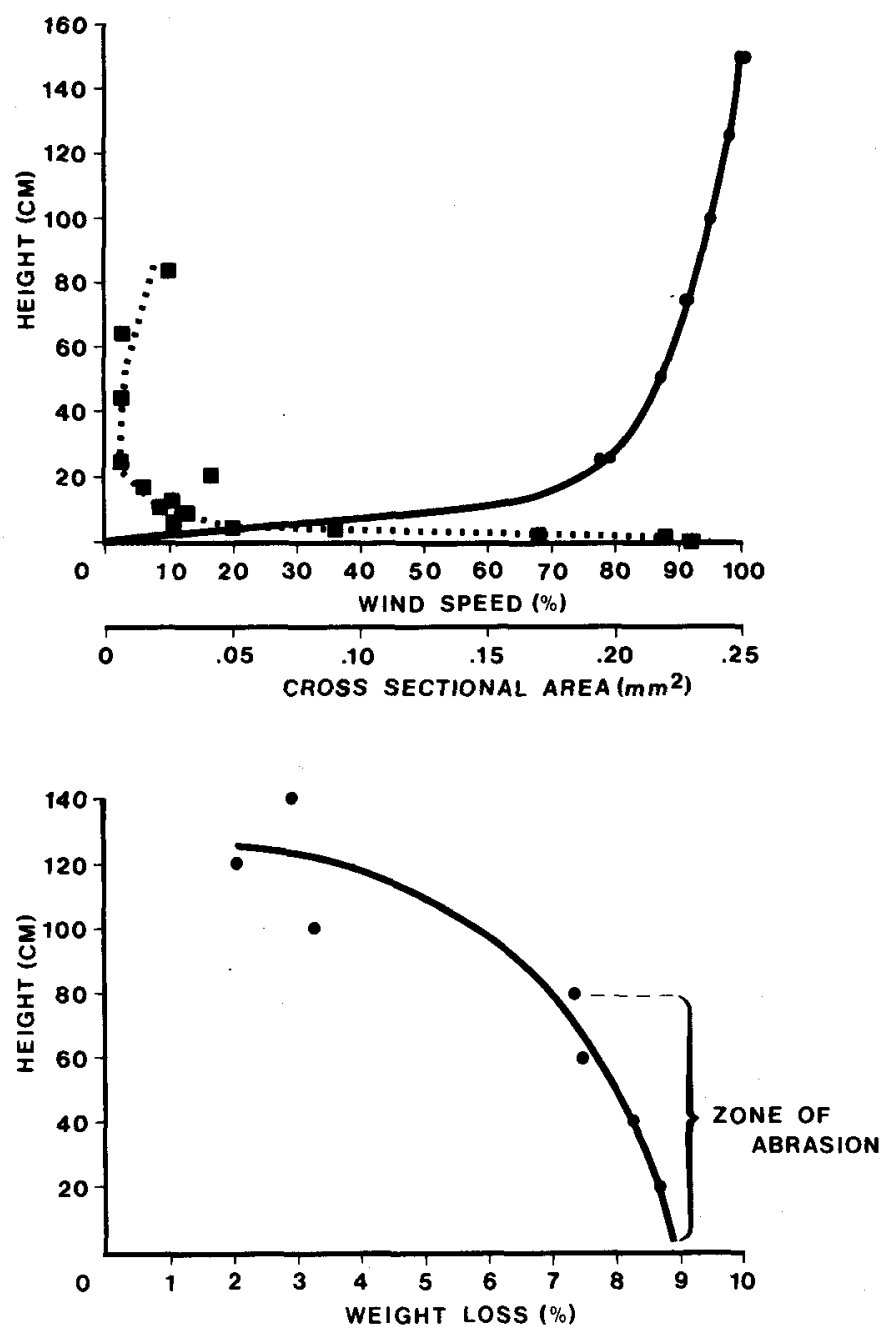

FIG. 1. Wind speed profiles taken at $25 \mathrm{~cm}$ intervals above the snow surface during a typical $20 \mathrm{~km} \cdot \mathrm{h}^{-1}$ and $30 \mathrm{~km} \cdot \mathrm{h}^{-1}$ wind during February at Churchill, Manitoba (top, circles). Wind speed is least near the surface, where the ice crystals are numerous and very large (top, squares). Ice crystal size decreases rapidly to a minimum in the first $10 \mathrm{~cm}$, then increases slightly up to the first metre. Above $10 \mathrm{~cm}$ the crystal size is variable due to changes in form. The change in weight due to needle loss at various heights above the snow surface of 3-year-old white spruce branchlets after 10 days of abrasion by wind-driven ice crystals is also shown (bottom). Consistent abrasion is limited to the first $80 \mathrm{~cm}$ above the snow surface.

The two-year-old white spruce branchlets placed $10 \mathrm{~cm}$ above the snow surface for 7 days lost from 4 to $7 \%$ of their initial weight. Although the weight loss due to needle damage was highly variable, some trends are evident (Fig. 2). Branchlets from the forest-tundra trees consistently lost more needles than branchlets from full-crowned trees. This difference is significant for branchlets from the seven-yearold branches $(t=3.75, p<.01)$, which were most resistant to needle loss. Greatest needle loss occurred in branchlets from three-year-old and eleven-year-old branches. This confirms the field observation that lower branches (older than ten years) often lose all of their needles in a single blizzard, while younger branches are more resistant (Fig. 3).

The wind speed around both islands of white spruce declined to approximately $90 \%$ of the reference value on the upwind side and increased by similar proportions on the 


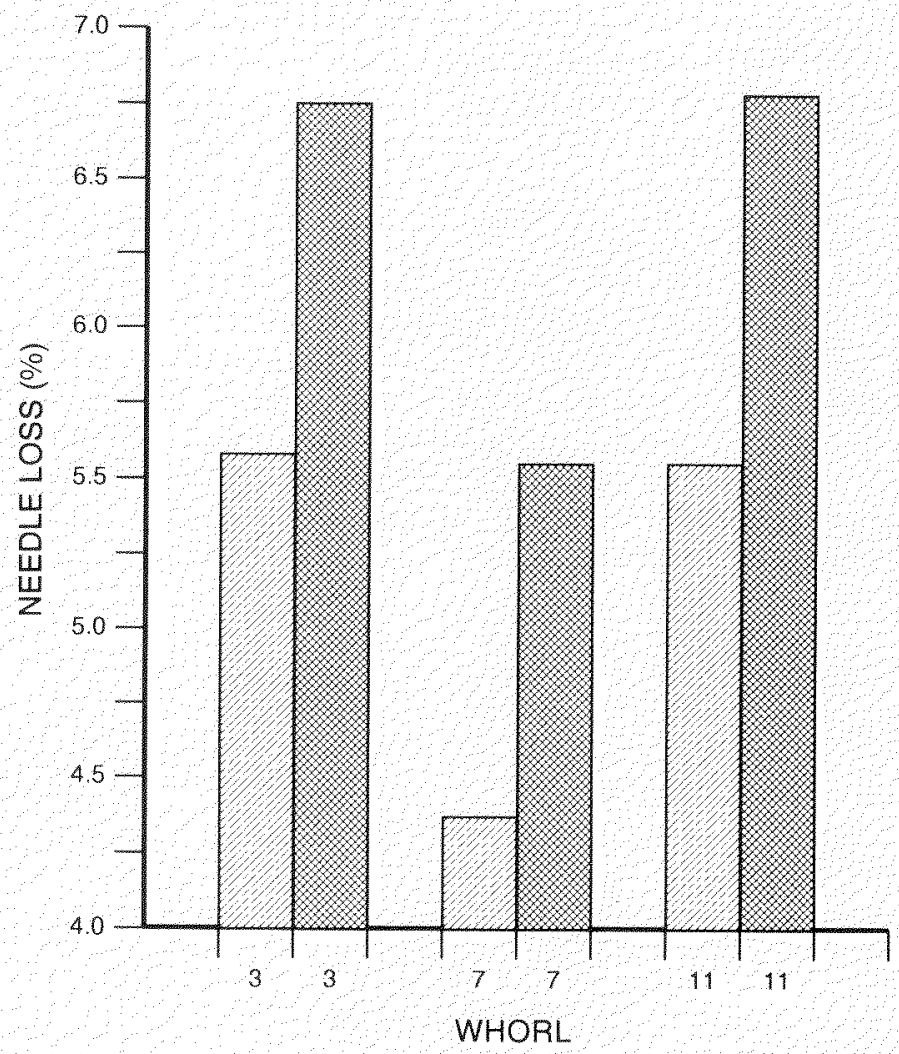

FIG. 2. The change in weight due to needle loss of 2-year-old branchlets from 3-, 7-and 11-year-old branches of full-crowned (hatched bars) and abraded-crowned (cross-hatched bars) tree-line white spruce.
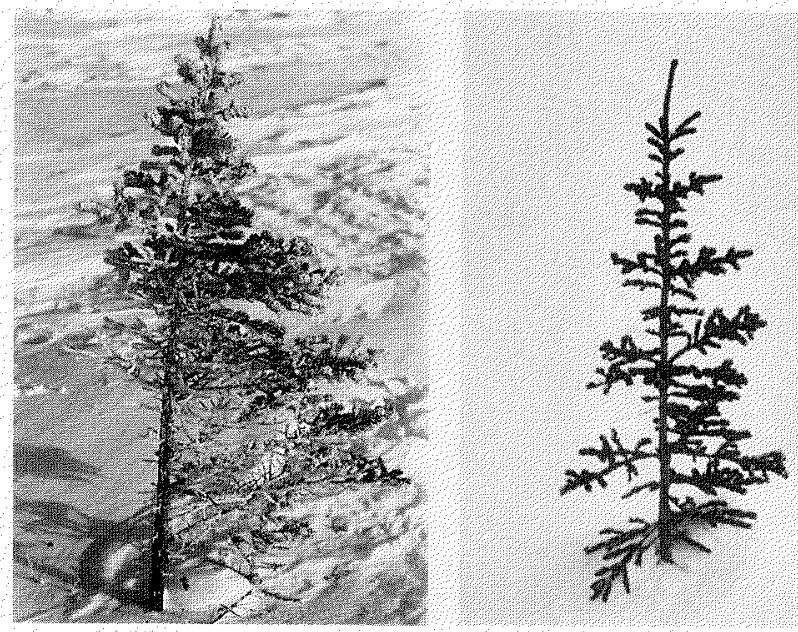

FIG. 3. Different aged branches have different resistance to abrasion. These white spruce trees were covered up to their present level during a rare heavy snow just prior to a blizzard. The tree on the left had much older branches in the zone of abrasion than the tree on the right. On the left, the needles on branches older than 7 years as well as the branches were completely abraded away during the blizzard. On the right, the 7-yearold branches near the surface resisted abrasion, although the 3- and 4-yearold branches were moderately damaged on the upwind side.

cross-wind sides (Fig. 4). When compared to the reference value, the wind speed in the woodland declined to $80 \%$ on the upwind and cross-wind sides. The wind velocities immediately downwind of the islands were approximately $40 \%$ of the ambient wind speed and only $12 \%$ downwind of the woodland tree. In all three studies the minimal wind
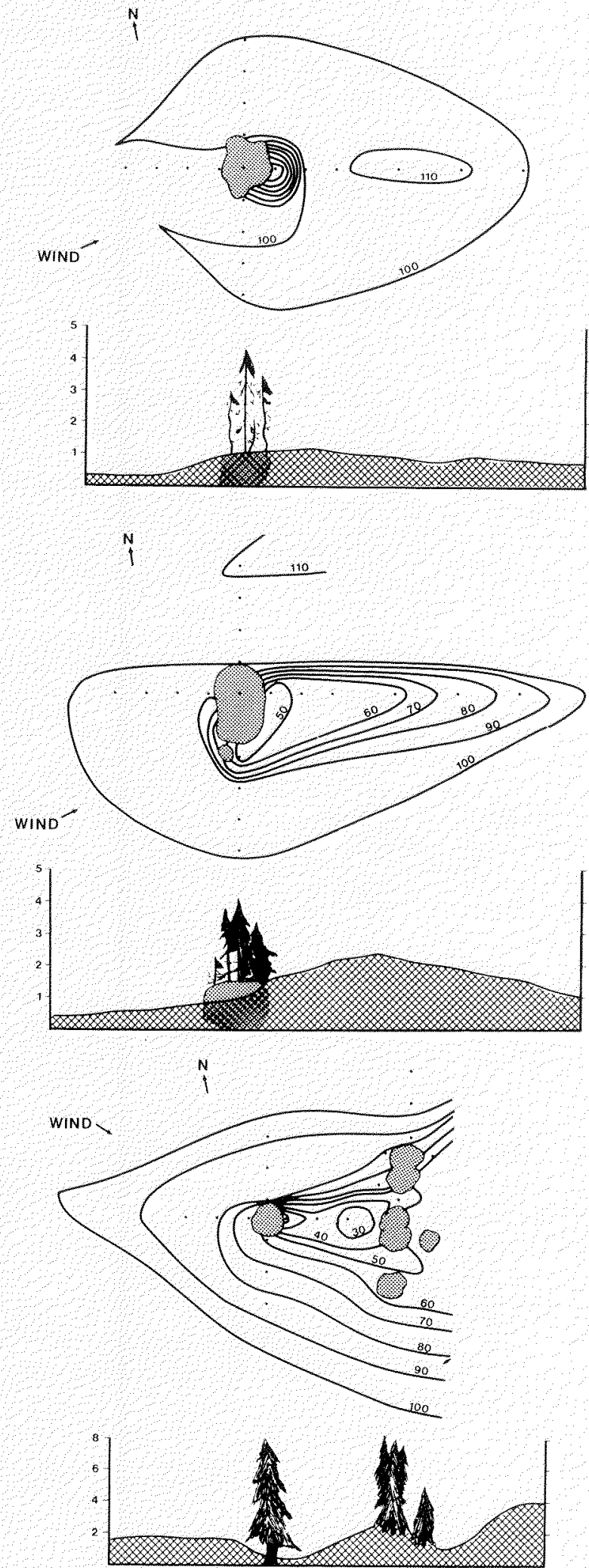

FIG. 4. Relative wind speeds and snow depths of the sparsely needled forest-tundra island (top), the densely needled forest-tundra island (middle) and from around a tree within a woodland (bottom). The basal mass of needles and branches, often referred to as a skirt or cushion, is shown (stippled) within the snowpack (cross hatching). Reference points are represented by dots. The horizontal and vertical scales are the same and given in metres on the left, except that the vertical scale is halved at the woodland site (bottom). 
speed was located immediately behind the stem(s) and gradually increased with distance downwind. Typical of most trees in the area, the densely needled island under study and some of the woodland trees had a distinct jet of relatively high-speed air moving through channels within or around the tree structure.

At the sparsely needled island, the horizontal depth profile of accumulated snow began at approximately $80 \mathrm{~cm}$ depth, 2-3 m upwind of the structure, gradually increasing to $110 \mathrm{~cm}$ which covers the basal mass of branches, and declining to $80 \mathrm{~cm}, 2-3 \mathrm{~m}$ downwind (Fig. 4). The resulting winter appearance of the island is that of an aggregation of dead, branchless and severely abraded stems protruding from a snowbank. Snow accumulation near the upwind side of the densely needled island was $75 \mathrm{~cm}$, and it increased to 150 $\mathrm{cm}$ within the island. A wind-scoured trough approximately $40 \mathrm{~cm}$ wide and $25 \mathrm{~cm}$ deep occurs just downwind of the island, but beyond this, in the lee, the snow surface rises to a peak at $200 \mathrm{~cm}$ depth approximately $3 \mathrm{~m}$ downwind. The woodland tree was situated in approximately $85 \mathrm{~cm}$ of snow, with very little upwind or cross-wind redistribution evident. The area underneath the foliage and immediately downwind had less than half the snow depth. Approximately $3 \mathrm{~m}$ downwind was a snow drift above the ambient level shaped as a plume. The snow deposition in the open forest was more or less uniform, with subtle contours associated with ground features such as stumps.

Over the five years of study, the mid-February average snow depth in the open forest ranged from $49 \mathrm{~cm}$ in 1988 to $75 \mathrm{~cm}$ in 1989 (Table 1). During mid-February, 1992, when data were collected from all tree-line environments, approximately $20 \mathrm{~cm}$ of snow had accumulated on ice surfaces, while $40 \mathrm{~cm}$ had accumulated on the exposed forest tundra. A maximum depth of $420 \mathrm{~cm}$ was measured in the forest-tundra woodland and up to $58 \mathrm{~cm}$ had accumulated in the open forest. Brown Beckel (1957) reports similar snow depths at Churchill during the early 1950s.

To compare with the measured snowfall at the Churchill Weather Office, the open forest data were converted to snowwater equivalents. The average water equivalent of the exposed forest-tundra snow column was $29 \%$ and the powder snow in the open forest was $25 \%$. These values are within the expected range based on measurement in other similar studies (Marchand, 1991; Timoney et al., 1992; Churchill Weather Office, Churchill, Manitoba) and are used here as an average of changing snow densities that will vary with temperature and season.

During early winter, the rate of snow accumulation in the open forest was approximately one and a half times that of the recorded snowfall (Fig. 5). As winter progressed, the rate of accumulation in the open forest increased, reaching three times the recorded snowfall during two of the three years studied.

\section{DISCUSSION}

Moving away from the snow surface, the increasing wind speed initially corresponds to a decrease in size and number of ice crystals. Frequent collisions with structures resistant to the airflow, such as spruce needles, creates the zone of abrasion, which is largely limited to the first $80 \mathrm{~cm}$ above the snow. Hollow and aerodynamically complex crystals are relatively sparse and dominate the upper portion of the abrasion zone and higher. The damage to leaf tissues on

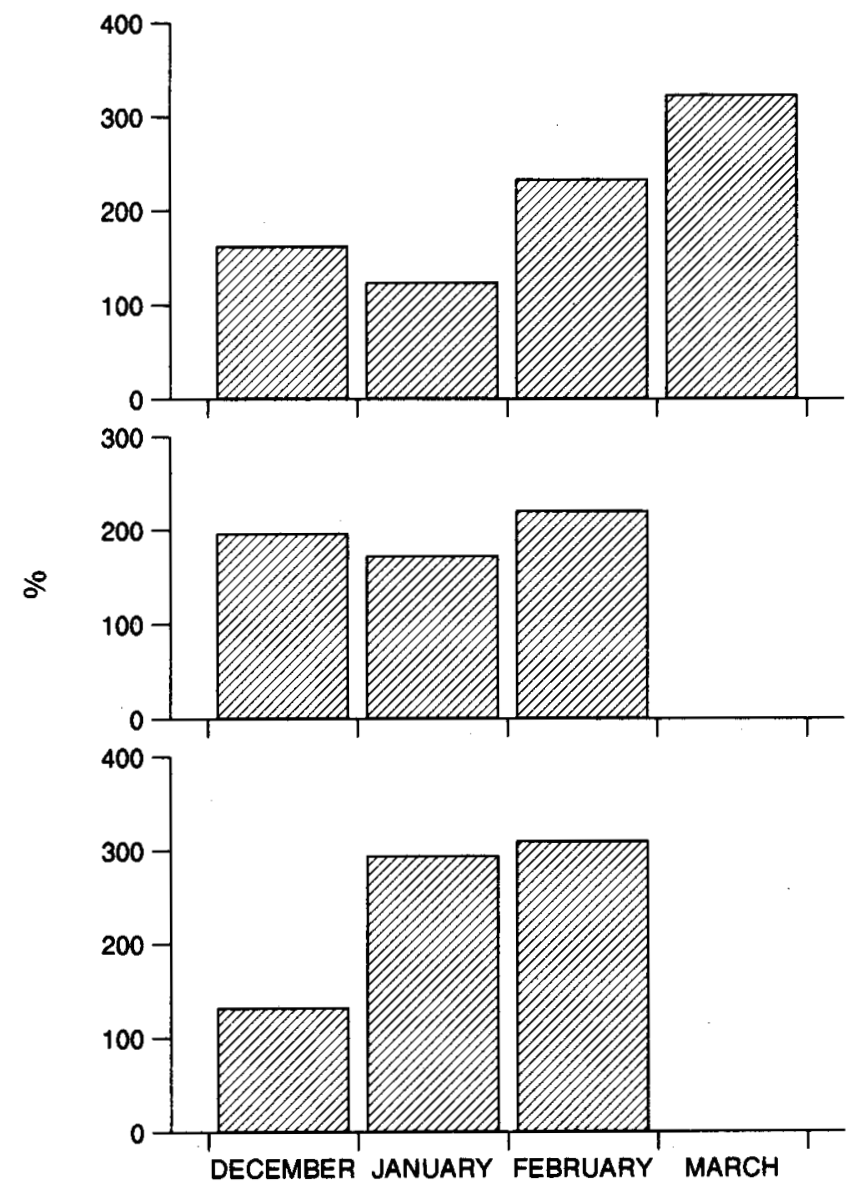

FIG. 5. The snow accumulation in the open forest as a percentage of the reported snowfall at the Churchill Weather Office during monthly periods in the winters of 1988-89 (top), 1989-90 (middle) and 1990-91 (bottom). The snowfall and snow depth figures were initially converted to water equivalents.

TABLE 1. Comparative snow depths in $\mathrm{cm}$ for Churchill, Manitoba, during mid-February

\begin{tabular}{|c|c|c|c|c|c|c|c|c|c|}
\hline \multirow[b]{2}{*}{ Year } & \multicolumn{2}{|c|}{ Sea ice } & \multicolumn{2}{|c|}{ Lake ice } & \multicolumn{2}{|c|}{ Forest tundra } & \multirow[b]{2}{*}{ Copse peak } & \multicolumn{2}{|c|}{ Open forest } \\
\hline & Avg & $\mathrm{SD}$ & Avg & SD & Avg & SD & & Avg & SD \\
\hline$\overline{1992}$ & 20.5 & 8.13 & 17.2 & 6.23 & 42.4 & 29.26 & 420.0 & 57.8 & 15.86 \\
\hline 1991 & - & - & - & - & - & - & - & 68.7 & 7.71 \\
\hline 1990 & - & - & - & - & - & - & - & 57.1 & 2.54 \\
\hline 1989 & - & - & - & - & 40.7 & 24.24 & 450.0 & 75.2 & 8.31 \\
\hline 1988 & - & - & 12.6 & 6.16 & 18.0 & 18.96 & 226.0 & 49.9 & 6.71 \\
\hline
\end{tabular}


impact would be greatest when the collision is most localized to the sharp edge of a complex crystal. Above the $80 \mathrm{~cm}$ level some needle removal occurs, but most commonly, cuticular abrasion that leads to desiccation during the growing season (Frey, 1983; Hadley and Smith, 1989) is prevalent. Cuticular damage was not quantified during the needle abrasion studies, although all of the trees were evidently already in a state of desiccation associated with the long, very cold winter period just before the study period (Scott and Hansell, 1992).

Needles from different locations throughout the tree have differences in susceptibility to damage by wind abrasion (Hadley and Smith, 1983). It was apparent during our study of white spruce branches in the zone of abrasion that needles of different age were of different size and susceptibility to being completely abraded away. Further, needles of the same age had differing resistance to removal, reflecting the history of the tree (crown form) and the age of the branch. Needles produced on new branches are initially susceptible to being abraded away. As the branches age over an 8-year period, each subsequent crop of needles becomes more resistant to being removed by abrasion. After 8 years, branches again become more susceptible to needle loss, and increasingly the seasonal crop of needles will be lost during the first winter. Consequently, to successfully grow through the abrasion zone, shoot growth should exceed $80 \mathrm{~cm}$ in 7 or 8 years.

In this study the trees that were successful at Churchill grew $80 \mathrm{~cm}$ in 6.4 years on average. This amount of growth is typical of measurements in other local studies as well (Scott et al., 1987, 1988). Once through the abrasion zone, new branches develop with needles largely remaining intact but are prone to cuticular damage from a lesser intensity of abrasion (Hadley and Smith, 1989). As lower branches become older, needle loss within $80 \mathrm{~cm}$ of the snowpack surface accelerates, leading to localized branch loss and stem damage. In fact, most abraded stems of the forest-tundra white spruce are reddish, as they have lost all dead bark on the upwind side, and resin blisters are common, indicating damage to the living phloem within the bark. The removal of needles and branches and bark loss apparently do not significantly impede wood production or height growth in the stem (Fig. 6).

In the extreme condition, low ground temperatures produce poor growth (Delucia, 1986; Scott et al., 1987; Day et al., 1991), resulting in a prolonged period in the most severe zone of abrasion and frequent loss of the terminal buds. The subsequent disorganization leads to even poorer growth, which often results in failure to erect a shoot through the abrasion zone. However, the krummholz tree islands on the forest tundra, mostly stemless mats and cushions (see Payette, 1974; Marr, 1977; Scott et al., 1987; Marchand, 1991; Lavoie and Payette, 1992), are least exposed to abrasion. These islands accumulate snow early in the season and remain buried throughout the winter. Snow infilling also characterizes the islands that are sparsely needled, as depicted in Figure 4 (top). The snow cover may reduce winter desiccation (Tranquillini, 1979; Hadley and Smith, 1987), but delayed snowmelt often results in low ground temperatures during the growing season (Brown Beckel, 1957; Rouse, 1984a).

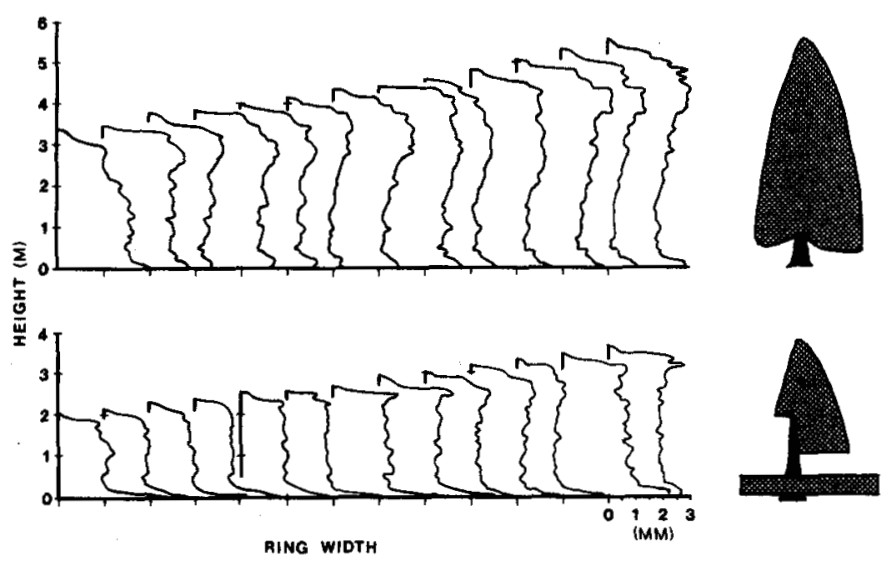

FIG. 6. The annual growth layers (i.e., the average annual growth ring along the entire stem) for a full-crowned (top) and an abraded-crowned (bottom) white spruce during 1970-82. While narrow ring widths occur in the bare trunk at the bottom of the full-crown tree, narrow rings are not evident in the bare abrasion zone of the abraded tree. This may be because of contributions to the ring from the dense growth of needles in the basal mass below (from Hansell et al., 1984).

The density of a wind barrier is directly proportional to the height of the plume (snow depth) and inversely proportional to its length (Oke, 1987:245). Densely needled islands reduce winter airflow and trap most snow in such a plume on the downwind side. The redistribution of snow appears to enhance establishment of shrubs such as Betula glandulosa, light-tolerant mosses such as Tomenthypnum nitens and other snow-bed species. Areas downwind to slightly cross-wind of the islands produced jets where upwardly displaced air moves back down to the surface. On the upwind side, and where jets occur, lichen-heath develops. High-speed air jets develop in front of the cushion (or skirt) of the tree island and on the right-hand side (while viewing from upwind), which partially removes the snow. The cushions with the direct impact from the jets have the most densely needled branches, which often become encrusted with ice and snow.

Over long periods of time there may be a trend towards woodland development on the forest tundra. Marr (1977) suggests that high-speed jets create unfavourable conditions between tree islands, which would become more severe as the gap between them narrowed. This would prevent the islands from growing laterally, coalescing and forming woodlands. At Churchill, woodland formation appears to develop along ridges and in wind-sheltered sites, where spruce islands become grouped. The subsequent height increase from ongoing stem growth and decline in barrier density due to needle loss lengthen the area of snow accumulation downwind, eventually filling in between the islands. Within the woodland complex, high-speed wind jets form an asymmetric horseshoe-shaped vortex (Kind, 1981) around the base of some stems, clearing snow from beneath the raised cushions (Adams, 1981; Kind, 1981). Snow loading on the branches of most trees occurs frequently during quiet periods and in areas with the greatest shelter from the wind. During our study, the snow beneath the woodland study tree was moved out from under the crown and deposited in the branches on the downwind side (Fig. 4, bottom). 
In the open forest, the air movement was minimal at the snow surface during periods of measurement and heavy snow load on the trees was common (e.g., Pruitt, 1978; Marchand, 1991). Snow was also absent under open forest trees at the edge of clearings. Such trees develop in association with frost heaving and subsequent palsa development, resulting in “drunken forests" (e.g., Marchand, 1991). Seppala (1986) created similar palsas, without trees, by removing snow from peatlands during the winter.

Snowfall is generally blown southward off Hudson Bay and adjacent lowlands, especially off the lake ice and exposed areas of the forest tundra. The stemless white spruce islands become snow covered early in the season, whereas the islands with stems collect shifting plumes of snow. During midwinter the forest-tundra woodlands fill to capacity and snow accumulation in the open forest is approximately twice the measured snowfall. During late winter the rate of snow accumulation that results from redistribution of snow across the tree line increases to approximately three times the measured rate of snowfall. This pattern also varies with wind speed and direction. For example, during years of heavy winds, the woodlands fill to a higher peak and earlier in the season. However during late winter in 1989-90, west winds resulted in snow blowing away from the open forest and the accumulation did not increase. In exposed areas that contribute snow, the distribution of snow is relatively uniform, although the net accumulation is less than the measured rate of snowfall. The distribution of snow is more variable across a gradient of spruce islands and woodlands approaching the tree line. The snow distribution is more uniform again within the open forest.

In spring, snowmelt on the exposed tundra usually occurs in late May (Brown Beckel, 1957; Rouse, 1982). The ground is frozen during snowmelt and most free water will readily run off or evaporate (Lafleur et al., 1992). Consequently, the contribution of snowmelt to ground water recharge and the subsequent availability for biological organisms is limited and can be highly variable (Marsh and Woo, 1985). Snowmelt in the open forest is usually three weeks later than on the exposed forest tundra and tundra. The larger quantities of water result in greater net percolation into the thawing peat (Rouse, 1982). Under near-average conditions, more heat would be required to warm the water immediately after snowmelt and the canopy might further reduce the availability of required latent heat of evaporation, contributing to a delay in warming of the forest (Rouse, 1984b; Scott et al., 1987; Odin and Degermark, 1990). In woodlands, snowmelt is usually completed by mid-July. Woodlands are characterized by snowbed communities commonly found on the downwind side, where the snow accumulation is greatest. Snowfall typically begins during mid-September.

\section{ACKNOWLEDGEMENTS}

We acknowledge the field assistance of R. Bello, C. Bentley, G. Hart, R. Staniforth, A. Szeredi and S. Wilkerson. Helpful discussions were undertaken with R. Bello, D. Fayle, P. Lafleur and W. Rouse. We thank D. Carlson, I. Craine, D. Fayle, J. Hadley, B. Howland and S. Payette for helpful comments on the manuscript. Additional equipment was generously provided by
R. Bello, R. Bentley, W. Rouse and P. Adams. Snowfall data and information were provided by the Churchill Weather Office, Churchill, Manitoba. Logistics were provided through the Churchill Northern Studies Centre (CNSC), D. DeMeulles, C. Paddock and L. Lee. Funding was provided by NSERC, the Northern Scientific Training Program and the CNSC.

\section{REFERENCES}

ADAMS, W.P. 1981. Snow: Plants and animals. In: Gray, D.M., and Male, D.H., eds. Handbook of snow: Principles, processes, management and use. Toronto: Pergamon Press. 3-31.

BROWN BECKEL, D.K. 1957. Studies on the seasonal changes in the temperature gradient of the active layer of soil at Fort Churchill, Manitoba. Arctic 10:151-183.

CLARK, J. 1961. Photosynthesis and respiration in white spruce and balsam fir. Syracuse University, State College of Forestry Technical Publication 85.72 p.

DAY, T.A., HECKATHORN, S.A., and DELUCIA, E.H. 1991. Limitations of photosynthesis in Pinus taeda L. (Loblolly Pine) at low soil temperatures. Plant Physiology 96:1246-1254.

DELUCIA, E.H. 1986. Effect of low root temperature on the net photosynthesis, stomatal conductance and carbohydrate concentration in Engelmann spruce (Picea engelmannii Parry ex Engelm.) seedlings. Tree Physiology 2:143-154.

FREY, W. 1983. The influence of snow on growth and survival of planted trees. Arctic and Alpine Research 15:241-251.

GOODISON, B.E., FERGUSON, H.L., and McKAY, G.A. 1981. Measurement and data analysis. In: Gray, D.M., and Male, D.H., eds. Handbook of snow: Principles, processes, management and use. Toronto: Pergamon Press. 191-274.

GRIER, C.C. 1988. Foliage loss due to snow, wind, and winter drying damage: Its effects on leaf biomass of some western conifer forests. Canadian Journal of Forest Research 18:1097-1102.

HADLEY, J.L., and SMITH, W.K. 1983. Influence of wind exposure on needle desiccation and mortality for timberline conifers in Wyoming. U.S.A. Arctic and Alpine Research 15:127-135.

1987. Influence of krummholz mat microclimate on needle physiology and survival. Oecologia 73:82-90.

. 1989. Wind erosion of leaf surface wax in alpine timberline conifers. Arctic and Alpine Research 21:392-398.

HANSELL, R.I.C., SCOTT, P.A., and FAYLE, D.C.F. 1984. Study on temporal development of subarctic ecosystems - Determination of the relationship between tree-ring increments and climate. Report to Department of Supply and Services for Atmospheric Environment Service, Downsview. Contract \#OSU84-00041. Available at AES, 4905 Dufferin Street, Downsview, Ontario M5H 5T4.

KIND, R.J. 1981. Snow drifting. In: Gray, D.M., and Male, D.H., eds. Handbook of snow: Principles, processes, management and use. Toronto: Pergamon Press. 338-359.

KULLMAN, L. 1990. Dynamics of altitudinal tree-limits in Sweden: A review. Norsk Geografisk Tidsskrift 44:103-116.

LAFLEUR, P.M., ROUSE, W.R., and CARLSON, D.W. 1992. Energy balance differences and hydrological impacts across the northern treeline. International Journal of Climatology 12:193-203.

LAVOIE, C., and PAYETTE, S. 1992. Black spruce growth forms as a record of a changing winter environment at treeline, Quebec, Canada. Arctic and Alpine Research 24:40-49.

MARCHAND, P.J. 1991. Life in the cold. Hanover, N.H.: University Press of New England.

MARR, J.W. 1977. The development and movement of tree islands near the upper limit of tree growth in the southern Rocky Mountains. Ecology 58:1159-1164.

MARSH, P., and WOO, M.-K. 1985. Meltwater movement in natural heterogenous snowcovers. Water Resources Research 21:1710-1716.

NAKAYANA, U. 1954. Snow crystals, natural and artificial. Cambridge: Harvard University Press. $510 \mathrm{p}$.

ODIN, H., and DEGERMARK, C. 1990 . The spring in the forest terrain at Svartberget, northern Sweden. Geografiska Annaler 72A:167-178.

OKE, T.R. 1987. Boundary layer climates. New York: Methuen.

PAYETTE, S. 1974. Classification écologique des formes de croissance de Picea glauca (Moench.) Voss et de Picea mariana (Mill.) BSP. en milieux subarctiques et subalpins. Le Naturaliste Canadien 101:893-903. 
1983. The forest-tundra and present treelines of the northern Quebec-Labrador peninsula. Nordicana 47:3-23.

PAYETTE, S., and FILION, L. 1985. White spruce expansion at the treeline and recent climatic change. Canadian Journal of Forest Research 15:241-251.

PRUITT, W.O. 1978. Boreal ecology. London: Edward Arnold.

ROUSE, W.R. 1982. Microclimate of low arctic tundra and forest at Churchill, Manitoba. In: Proceedings Fourth Canadian Permafrost Conference. 68-80.

1984a. Microclimate of the arctic treeline 2. Soil microclimate of tundra and forest. Water Resources Research 20:67-73.

. 1984b. Microclimate of the arctic treeline 1. Radiation balance of tundra and forest. Water Resources Research 20:56-66.

SCOTT, P.A., and HANSELL, R.I.C. 1992. Mid-winter weight gain of excised white spruce branchlets at the treeline. Canadian Journal of Forest Research 22:625-627.

SCOTT, P.A., BENTLEY, C.V., FAYLE, D.C.F., and HANSELL, R.I.C. 1987. Crown forms and shoot elongation of white spruce at the treeline, Churchill, Manitoba, Canada. Arctic and Alpine Research 19:175-186.
SCOTT, P.A., FAYLE, D.C.F., BENTLEY, C.V., and HANSELL, R.I.C. 1988. Large scale changes in atmospheric circulation interpreted from patterns of tree growth at Churchill, Manitoba, Canada. Arctic and Alpine Research 20:199-211.

SEPPALA, M. 1986. The origin of palsas. Geografiska Annaler 68A:141-147.

STEVENS, G.C., and FOX, J.F. 1991. The causes of treeline. Annual Review of Ecology and Systematics 22:177-191.

TIMONEY, K., KERSHAW, G.P., and OLESEN, D. 1992. Late winter snow-landscape relationships in the subarctic near Hoarfrost River, Great Slave Lake, Northwest Territories, Canada. Water Resources Research 28:1991-1998.

TRANQUILLINI, W. 1979. Physiological ecology of alpine timberline. Berlin: Springer-Verlag. 137 p.

WARDLE, P. 1981. Winter desiccation of conifer needles simulated by artificial freezing. Arctic and Alpine Research 13:419-423.

YOSHINO, M.M., 1973. Wind-shaped tree in the subalpine zone in Japan. Arctic and Alpine Research 5:115-126. 